\title{
Immunochemical Characterization of the Cell Surface Carbohydrate Antigens of Peptostreptococcus anaerobius
}

\author{
By GILLIAN L. F. SMITH, ${ }^{1}$ C. G. CUMMING ${ }^{2}$ AND P. W. ROSS ${ }^{1 *}$ \\ ${ }^{1}$ Department of Bacteriology, University Medical School, Teviot Place, Edinburgh EH8 9AG, UK \\ 'Department of Oral Medicine and Oral Pathology, Old Surgeons Hall, High School Yards, \\ Edinburgh EHI INR, UK
}

(Received 11 June 1985; revised 11 September 1985)

\begin{abstract}
Two carbohydrate antigens were isolated from the cell surface of Peptostreptococcus anaerobius. One, extracted from purified cell walls with $\mathrm{NaOH}$, contained glucose and phosphorus, with traces of galactosamine and glucosamine. Serological activity was detected by a 'dot blot' procedure. The second antigen, extracted from cell membranes with phenol and purified by chromatography on Sepharose 6B and an immunoadsorbent column, contained glucose, glycerol phosphate, phosphorus and fatty acids. Antigenicity of this extract could also be demonstrated by an ELISA technique.
\end{abstract}

\section{INTRODUCTION}

Peptostreptococcus anaerobius is one of the Gram-positive anaerobic cocci (GPAC) most commonly isolated from human clinical samples (Wideman et al., 1976; Smith et al., 1986); few now question their association with a wide range of infections, many of which may be lifethreatening.

The classification of GPAC is based on the biochemical and morphological characteristics of the organisms (Holdeman et al., 1977). However, many of the clinically significant GPAC isolated from human infections are relatively inert and defy further classification. Serological characteristics of GPAC have been examined in an effort to find a reproducible and practical basis for classification (Stone, 1940; Porschen \& Spaulding, 1974; Markowitz \& Lerner, 1977), but no definitive scheme has emerged. Aspects of the cell wall composition of GPAC have been reported in some detail (Bahn et al., 1966) but specific attention has not been paid to the secondary cell wall polymers, also known as the teichoic acids (or their analogues). These carbohydrates, covalently bound to peptidoglycan, have been used in serological studies of other Gram-positive cocci (Lancefield, 1933; Cumming et al., 1981) and Clostridium difficile (Poxton \& Cartmill, 1982).

The present study is the first to investigate the nature of both the secondary wall polymers and the membrane lipocarbohydrates (lipoteichoic acids or their analogues) of $P$. anaerobius as the possible basis of a serological classification scheme for GPAC.

\section{METHODS}

Bacteria. The strain of $P$. anaerobius used in this study (GPAC 56393, supplied by Dr Brian Watt (City Hospital, Edinburgh, UK) was isolated from a case of otorrhoea. The organism was stored in $10 \%(\mathrm{w} / \mathrm{v})$ skimmed milk at $-20{ }^{\circ} \mathrm{C}$. A stock culture of GPAC 56393 was prepared by adding a few drops of thawed skimmed milk preparation to $10 \mathrm{ml}$ of modified Robertson's cooked meat medium (CMB; Watt, 1972) which had been prereduced by boiling for $10 \mathrm{~min}$. This CMB was incubated in an anaerobic jar (Baird \& Tatlock) for $48 \mathrm{~h}$ at $37^{\circ} \mathrm{C}$

\footnotetext{
Abbreviations: GPAC, Gram-positive anaerobic cocci: CMB, cooked meat medium; PPY, proteose-peptone
} yeast medium; RIE, rocket immunoelectrophoresis; BBS, borate-buffered saline. 
Culture techniques. The CMB culture was used to inoculate 101 of pre-reduced proteose-peptone yeast medium (PPY) (Holbrook et al., 1978) containing L-cysteine hydrochloride and sodium carbonate at final concentrations of $0.075 \%$ and $0.04 \%$ respectively. This medium was incubated in an anaerobic cabinet (Forma Scientific Anaerobic System, Model 1024; Marietta, Ohio, USA) at $37^{\circ} \mathrm{C}$ for $18 \mathrm{~h}$.

Preparation of wall antigen. Bacteria were harvested by centrifugation at $1000 \mathrm{~g}$ for $30 \mathrm{~min}$ at $4{ }^{\circ} \mathrm{C}$ and washed twice in phosphate-buffered saline (PBS; 50 mu-sodium phosphate buffer, $\mathrm{pH} \mathrm{7.5,} \mathrm{with} 0 \cdot 15 \mathrm{M}-\mathrm{NaCl}$ ). The cell pellet was resuspended in $40 \mathrm{ml}$ distilled water at $4{ }^{\circ} \mathrm{C}$, and the bacteria were disrupted by being passed twice through a French pressure cell (Aminco) at 7000$) \mathrm{lbf} \mathrm{in}^{-2}(48 \mathrm{MPa})$. The resulting suspension was centrifuged at $52000 \mathrm{~g}$ for $15 \mathrm{~min}$ at $4{ }^{\circ} \mathrm{C}$ and the membrane-containing supernate was removed and freeze-dried for subsequent extraction of antigen. The pellet of cell walls was resuspended in distilled water and heated at $80^{\circ} \mathrm{C}$ for $3 \mathrm{~min}$ to destroy autolytic enzymes. To remove non-covalently bound protein and membrane fragments, an equal volume of $5 \%(\mathrm{v} / \mathrm{v})$ sodium dodecyl sulphate (SDS) was added and the suspension stirred at room temperature for $4 \mathrm{~h}$. SDS was removed by six successive washes in distilled water, centrifuging between each wash at $50000 \mathrm{~g}$. Finally, the cell wall pellet was freeze-dried. The carbohydrate secondary wall polymers were extracted according to the method of Archibald et al. (1969). A portion of the freeze-dried cell wall pellet was suspended in $0.5 \mathrm{M}-\mathrm{NaOH}$ and stirred at room temperature for $2 \mathrm{~h}$. This extract was centrifuged at $50000 \mathrm{~g}$ for $15 \mathrm{~min}$ and the supernate containing the secondary wall polymer was passed through an ion-exchange column (Dowex 50, BDH) to remove $\mathrm{Na}^{+}$ions. The eluate from the column was freeze-dried. The carbohydrate was purified further by applying the freeze-dried extract, dissolved in distilled water, to a $30 \times 1.5 \mathrm{~cm}$ DEAE cellulose ion-exchange column (DE52, Whatman). The extract was eluted with a downward flow of $0 \cdot 1 \mathrm{M}$-pyridine acetate buffer, $\mathrm{pH} 5 \cdot 3$, from a gradient mixer. Fifty fractions of $2 \mathrm{ml}$ were collected and assayed for their carbohydrate content.

Preparation of membrane antigen. A portion of the freeze-dried supernate obtained after cell breakage was treated according to the method of Coley et al. (1975). The material was defatted with three successive washes in chloroform and methanol $(2: 1, \mathrm{v} / \mathrm{v})$. The residue was left to dry in air then resuspended in $80 \%(\mathrm{w} / \mathrm{v})$ phenol and stirred at $4{ }^{\circ} \mathrm{C}$ for $40 \mathrm{~min}$. After centrifugation at $16000 \mathrm{~g}$ for $30 \mathrm{~min}$, the upper aqueous layer was dialysed overnight against distilled water, and then reduced in volume by rotary evaporation. This solution was incubated under toluene at $37^{\circ} \mathrm{C}$ for $72 \mathrm{~h}$ with RNAase (salt and protease-free) and DNAase (crude) (Sigma: $10 \mu \mathrm{g}$ of each

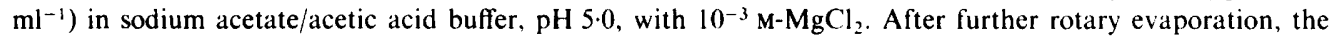
phenol extraction and dialysis procedures were repeated and the solution of lipoteichoic acid finally freeze-dried. This crude phenol extract was then purified on a $40 \times 1.6 \mathrm{~cm}$ Sepharose $6 \mathrm{~B}$ column (Pharmacia) eluted with $0.2 \mathrm{M}$-ammonium acetate buffer, $\mathrm{pH} 6.9$, containing $0.01 \%$ sodium azide. Fifty $3 \mathrm{ml}$ fractions were collected and assayed for carbohydrate, nucleic acid and phosphorus.

Analytical techniques. Carbohydrates, as glucose equivalents, were assayed by the phenol-sulphuric acid method of Dubois et al. (1956); phosphorus was assayed by the method of Chen et al. (1956) and sialic acid by the thiobarbituric acid method of Aminoff (1961). Protein content was determined by the Lowry method.

Preparation of antisera to $P$. anaerobius. Two New Zealand White rabbits were inoculated intravenously with live bacteria (GPAC 56393), which had been washed and suspended in PBS (a single injection on three consecutive days of $10^{\circ}$ organisms in $1 \mathrm{ml}$ PBS was given each week for four weeks). Antibody titres were determined from test bleeds using an ELISA technique (Poxton \& Byrne, 1981). EDTA extracts of GPAC at a concentration of $30 \mu \mathrm{g}$ protein $\mathrm{ml}^{-1}$ were used in this procedure. Animals were exsanguinated in the fifth week and their sera pooled.

Immunoelectrophoresis. Rocket immunoelectrophoresis (RIE) (Svendson, 1973) was done using a Shandon Southern apparatus.

Preparation of alditol acetates. Cell wall and membrane carbohydrates were hydrolysed in $2 \mathrm{M}-\mathrm{HCl}$ at 100 " $\mathrm{C}$ for $2 \mathrm{~h}$ and then converted to alditol acetates for analysis by gas-liquid chromatography (GLC) as described by Poxton \& Cartmill (1982). For detection of pentose and hexose derivatives, $1 \mu 1$ samples were injected into a column of $3 \%$ SP2330 on Supelcoport; amino sugar derivatives were analysed on a column of $3 \% \mathrm{OV} 225$ on Gas-Chrom Q. For both columns, temperatures were programmed to run between 190 and $240{ }^{\circ} \mathrm{C}$, increasing by $2^{\circ} \mathrm{C} \mathrm{min}^{-1}\left(\mathrm{Pye}^{\circ}\right.$ Unicam model 104 gas chromatograph).

Preparation of methyl esters. Methyl esters of latty acids in the IgG-purified membrane lipoteichoic acid (see below) were prepared by heating the lipoteichoic acid with $0.5 \mathrm{M}-\mathrm{HCl}$ in methanol at $65{ }^{\circ} \mathrm{C}$ for $2 \mathrm{~h}$. After partitioning into ether, GLC analysis was done using a column of $3 \%$ SP2330 on Supelcoport at $150{ }^{\circ} \mathrm{C}$.

Preparation of an immunoadsorbent column. Immunoglobulin $\mathrm{G}$ was prepared from $3 \mathrm{ml}$ pooled antisera raised against GPAC 56393 by the addition of $2 \mathrm{ml}$ saturated ammonium sulphate. This mixture was stirred at room temperature for $15 \mathrm{~min}$. After centrifugation at $600 \mathrm{~g}$, the supernate was removed and the precipitated $\mathrm{IgG}$ dissolved in $2 \mathrm{ml}$ PBS for dialysis against distilled water for $18 \mathrm{~h}$.

The column was prepared according to the methods outlined in Affinity Chromatography, Principles and Methods (Pharmacia). Precipitated IgG was coupled to $10.5 \mathrm{ml} \mathrm{CNBr-activated} \mathrm{Sepharose} \mathrm{4B} \mathrm{(Pharmacia)} \mathrm{and} \mathrm{this}$ material packed into a $10 \times 1 \mathrm{~cm}$ column. The storage buffer consisted of $0 \cdot 1 \mathrm{~m}$ phosphate, $\mathrm{pH} 7 \cdot 0$, with $0 \cdot 5 \%(\mathrm{v} / \mathrm{v})$ Tween 80 and $0.01 \%(\mathrm{w} / \mathrm{v})$ merthiolate. The column was equilibrated in borate-buffered saline (BBS; $0 \cdot 1 \mathrm{M}-\mathrm{NaCl}$, 
0.2 $\mathrm{M}$-disodium tetraborate, $\mathrm{pH} \mathrm{7.3)} \mathrm{to} \mathrm{avoid} \mathrm{phosphate} \mathrm{in} \mathrm{the} \mathrm{storage} \mathrm{buffer} \mathrm{contaminating} \mathrm{the} \mathrm{eluate.} \mathrm{After}$ freeze-drying the material from each peak was dissolved in $1 \mathrm{ml}$ BBS to give a carbohydrate concentration of approximately $1 \mathrm{mg} \mathrm{ml}^{-1}$ and applied separately with a downward flow of $20 \mathrm{ml} \mathrm{BBS}$. To elute the antigens, sodium carbonate buffer, $\mathrm{pH} 9 \cdot 6 / \mathrm{ethylene}$ glycol $(1: 1, \mathrm{v} / \mathrm{v})$ was applied in the reverse direction. Ten $4 \mathrm{ml}$ fractions were collected and, following dialysis, each was assayed for its carbohydrate content.

Paper chromatography. To detect teichoic acids (ribitol and glycerol phosphate polymers), acid hydrolysates of wall and membrane antigens were chromatographed on Whatman no. 1 paper with propan-1-ol/ammonia/water $(6: 3: 1$, by vol.) as solvent and stained with periodate-Schiff's reagent (Baddiley et al., 1956).

ELISA procedure. The method used was essentially that of Engvall \& Perlmann (1972), adapted for microtitre plates. Results were read in a Titretek Multiskan (Organon Teknika, St Neots, UK). Wall antigens, at a concentration of 30 and $50 \mu \mathrm{g}$ carbohydrate $\mathrm{ml}^{-1}$ were used to coat the plate wells. Membrane antigens, adjusted to $30 \mu \mathrm{g}$ protein $\mathrm{ml}^{-1}$, were treated similarly.

Dot-immunobinding procedure ('dot blotting'). The procedure of Hawkes et al. (1982) was followed, using the BioRad Immun-Blot assay kit. This system differs from the original method of Hawkes et al. (1982) in the use of gelatin instead of bovine serum albumin in the blocking solution. Antigens were suspended in distilled water to a concentration of $1 \mathrm{mg}$ carbohydrate (wall) or protein (membrane) $\mathrm{ml}^{-1}$ and added directly to nitrocellulose membrane $(0.2 \mu \mathrm{m}$ pore size $)$ in $1 \mu \mathrm{l}$ volumes.

\section{RESULTS}

Cell wall and carbohydrate preparation. The yield of cell walls from 101 of an $18 \mathrm{~h}$ culture of $P$. anaerobius was $285 \mathrm{mg}$. Total carbohydrate extracted with $\mathrm{NaOH}$ was $28 \mathrm{mg}$.

Cell wall antigen. The carbohydrate content of the 50 fractions from the DEAE cellulose column is shown in Fig. 1. A single major peak eluted between $0.15 \mathrm{M}$ and $0.22 \mathrm{M}$-pyridine acetate buffer. The fractions corresponding to this peak were pooled and concentrated by freezedrying, as were the remaining column fractions. The antigenic nature of each was assessed by RIE, ELISA and the 'dot blot' procedure. The latter technique indicated that peak material was antigenic, but no precipitin arcs were demonstrated in RIE; similarly, ELISA proved negative. GLC analysis of alditol acetates prepared from the peak material indicated that it consisted of glucose and an unknown sugar in approximately equal proportions, with traces of galactosamine and glucosamine. The unknown component had a retention time between those of the fucose and ribose standards, but coinjection ruled out these sugars and mannose as possible components. In addition, the antigen contained $123 \mu \mathrm{g}$ total phosphorus $\mathrm{ml}^{-1}$. No sialic acid or teichoic acids were detected in this antigen.

Cell membrane preparation. The yield of freeze-dried membrane-containing material from 101 of an $18 \mathrm{~h}$ PPY culture was $1.3 \mathrm{~g}$. The phenol extraction procedures yielded $56 \mathrm{mg}$ of crude lipoteichoic acids.

Cell membrane antigen. The elution profile of the crude phenol extract applied to Sepharose 6B is shown in Fig. 2. Two peaks were apparent, and fractions corresponding to these and the remaining column fractions were pooled and freeze-dried as already described. Both peak I and peak II contained antigen detected by ELISA and dot blotting although peak II gave a less intense reaction in the latter procedure. RIE of these peaks was not attempted, since this technique had proved negative with the crude phenol extract. To reduce nucleic acid contamination before chemical analysis, each peak was applied to an immunoadsorbent column containing IgG raised against whole cells. For each peak, a carbohydrate assay of eluted fractions revealed a single peak from the IgG column. ELISA and dot botting confirmed that both these IgG-purified peaks were still antigenic.

GLC analysis showed that each purified peak contained only glucose. Peak I material was methanolysed for analysis of its fatty acid content and subsequent analysis gave the following composition: C16:0 (11.8\% of total lipid), C16:1 (4.5\%), C18:0 (1.8\%), C18:1 (8.2\%), C18:2 $(2 \cdot 4 \%)$ and $\mathrm{C} 21: 0(71 \cdot 3 \%)$. No sialic acid was detected in this antigen, but it did contain glycerol phosphate. The antigen contained $10 \mu \mathrm{g}$ phosphorus $\mathrm{ml}^{-1}$.

Reproducibility of the above results was confirmed by repetition of all procedures on two further occasions. 


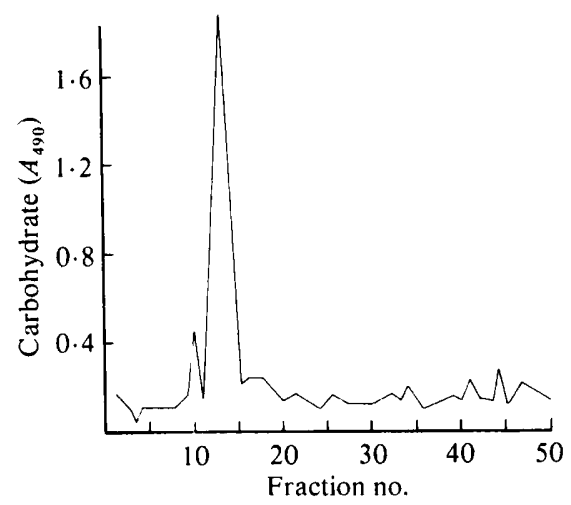

Fig. 1. Purification of a $\mathrm{NaOH}$ extract of SDS-treated cell walls of $P$. anaerobius by ion-exchange chromatography on a DEAE-cellulose column. An $A_{\$ 90}$ of 1.0 represents a carbohydrate content of $112 \mu \mathrm{g} \mathrm{ml}^{-1}$.

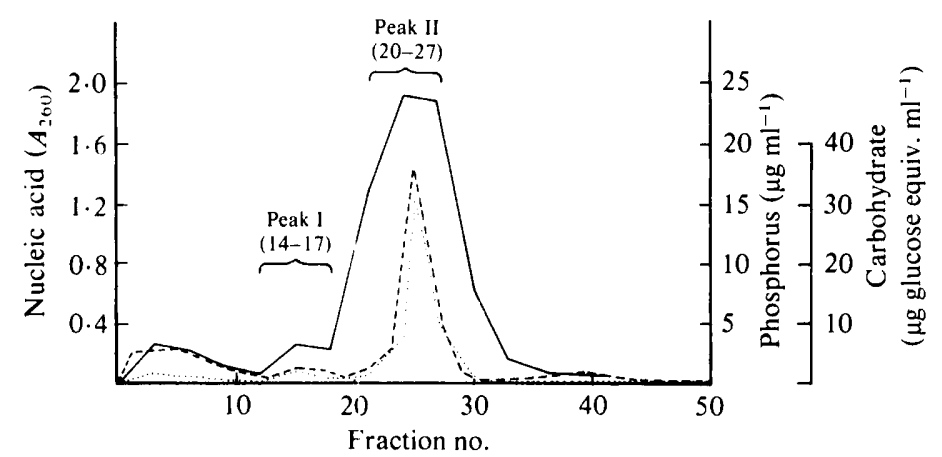

Fig. 2. Purification of a phenol extract of the cell membranes of $P$. anaerobius on a Sepharose $6 \mathrm{~B}$ column. - Nucleic acid: ---, carbohydrate; $\cdots$, phosphorus.

\section{DISCUSSION}

The current classification of GPAC by conventional tests is unsatisfactory and attempts to identify these bacteria by serological means have to date been unsuccessful. The present study examined cell surface carbohydrate antigens from a single strain of $P$. anaerobius to assess their potential as the basis for future serological studies involving a variety of GPAC.

$P$. anaerobius possesses two antigenic carbohydrate polymers that may be isolated from cell walls and membranes respectively. The membrane antigen contains glycerol phosphate and is therefore a lipoteichoic acid; the wall antigen contains neither glycerol nor ribitol phosphate, and therefore cannot be classed as a teichoic acid. Considerable difficulties were encountered in demonstrating the antigenicity of the cell wall carbohydrate. The extract did not form precipitating complexes with specific antibody in RIE and did not react in an ELISA procedure. The former may be explained by the antiserum raised against whole cells containing antibodies of low affinity for the wall antigen; for precipitation to occur, antigen must be added in high concentrations. This may be in stoichiometric excess, thus resulting in the formation of small, soluble antigen-antibody complexes. ELISA procedures may have been unsuccessful due to the antigen failing to adsorb to polystyrene (Gray, 1979). The antigenicity of the secondary cell wall polymer was finally demonstrated in a dot-immunobinding procedure, which is more sensitive than the alternative techniques tested. 
Antigenic activity in the membrane lipoteichoic acid was easier to demonstrate, although this extract also failed to precipitate with specific antibody in RIE. This made determination of any similarities between wall and membrane antigens difficult; Coley et al. (1975) suggested that the second peak from a Sepharose 6B column often contains secondary cell wall polymers and this was confirmed by Poxton \& Cartmill (1982) for $C$. difficile and by Cumming et al. (1983) for group B streptococcus, type II. Further work (unpublished) with $P$. anaerobius wall and membrane antigens using immunoblot transfer from polyacrylamide gels (Towbin et al., 1979) failed to demonstrate any similarity in the antigenic content of these extracts.

Several types of antigen are exposed at the cell surface of Gram-positive bacteria. This preliminary study examined the teichoic acid analogues and lipoteichoic acids present in the cell wall and membrane respectively of a single strain of $P$. anaerobius. Further studies are required, involving a variety of GPAC, before conclusions can be reached about the role of these antigens in a serological classification scheme. Similarly, the value of other cell surface antigens for this purpose should be investigated.

\section{REFERENCES}

AminofF, D. (1961). Methods for the quantitative estimation of $\mathrm{N}$-acetylneuraminic acid and their application to hydrolysates of sialomucoids. Biochemical Journal 81, 384-392.

Archibald, A. R., Coapes, H. E. \& Stafford, G. H. (1969). The action of dilute alkali on bacterial cell walls. Biochemical Journal 113, 899-900.

Baddiley, J., Buchanan, J. G., Handschumacher, R. E. \& PrescotT, J. F. (1956). Chemical studies in the biosynthesis of purine nucleotides. I. The preparation of $N$-glycolglycosylamines. Journal of the Chemical Society, 2818-2833.

BaHN, A. N., Kung, P. C. Y. \& Hayashi, J. A. (1966). Chemical composition and serological analysis of the cell wall of Peptostreptococcus. Journal of Bacteriology 91, 1672-1676.

Chen, P. S., Toribara, T. Y. \& Warner, H. (1956). Microdetermination of phosphorus. Analytical Chemistry 28, 1756-1758.

COLEY, J., DuCKWorth, M. \& BadDILEY, J. (1975). Extraction and purification of lipoteichoic acids from Gram-positive bacteria. Carbohydrate Research 40, 41-52.

Cumming, C. G., Ross, P. W. \& Poxton, I. R. (1981). Immunochemical studies on the cell-wall antigen of group B streptococcus, type Ib. Journal of General Microbiology 126, 477-482.

Cumming, C. G., Hay, A. J., Ross, P. W. \& Poxton, I. R. (1983). The isolation and immunochemical characterisation of a cell wall carbohydrate and a membrane lipocarbohydrate antigen of Group B streptococci type II. Journal of Medical Microbiology 16, 53-60.

Dubois, M., Gilles, K. A., Hamilton, J. K., Rebers, P. A. \& SMITH, F. (1956). Colorimetric method for the determination of sugars and related substances. Analytical Chemistry 28, 350-356.

Engvall, E. \& Perlmann, P. (1972). Enzyme-linked immunosorbent assay, ELISA. III. Quantitation of specific antibodies by enzyme-labelled anti-immunoglobulin in antigen-coated tubes. Journal of Immunology 109, 129-135.

GraY, B. M. (1979). ELISA methodology for polysaccharide antigens: protein coupling of polysaccharides for adsorption to plastic tubes. Journal of Immunological Methods 28, 187-192.
Hawkes, R., Niday, E. \& Gordon, J. (1982). A dotimmunobinding assay for monoclonal and other antibodies. Analytical Biochemistry 119, 142-147.

Holbrook, W. P., Ogston, S. A. \& Ross, P. W. (1978). A method for the isolation of Bacteroides melaninogenicus from the human mouth. Journal of Medical Microbiology 11, 203-207.

Holdeman, L. V., Cato, E. P. \& Moore, W. E. C. (1977). Anaerobe Laboratory Manual. Virginia Polytechnic Institute and State University: Blacksburg, Virginia.

LANCEFIELD, R. C. (1933). A serological differentiation of human and other groups of haemolytic streptococci. Journal of Experimental Medicine 57, 571-595.

Markowitz, A. \& LeRner, A. M. (1977). Differentiation of several isolates of Peptococcus magnus by counter-immunoelectrophoresis. Infection and Immunity 16, 152-154.

Porschen, R. K. \& Spaulding, E. H. (1974). Fluorescent antibody study of the Gram-positive anaerobic cocci. Applied Microbiology 28, 851-855.

Poxton, I. R. \& BYrne, M. D. (1981). Immunological analysis of the EDTA-soluble antigens of Clostridium difficile and related species. Journal of General Microbiology 122, 41-46.

PoXton, I. R. \& CARTMILL, T. D. I. (1982). Immunochemistry of the cell-surface carbohydrate antigens of Clostridium difficile. Journal of General Microbiology 128, 1365-1370.

Smith, G. L. F., Cumming, C. G. \& Ross, P. W. (1986). Survival of Gram-positive anaerobic cocci on swabs and their isolation from the mouth and vagina. Journal of Clinical Pathology (in the Press).

Stone, M. L. (1940). Studies on the anaerobic streptococcus. I. Certain biochemical and immunological properties of anaerobic streptococci. Journal of Bacteriology 39, 559-582.

SvENDSON, P. J. (1973). Fused rocket immunoelectrophoresis. Scandinatian Journal of Immunology 2, Suppl. 1, 69-70.

Towbin, H., Staehelin, T. \& Gordon, J. (1979). Electrophoretic transfer of proteins from polyacrylamide gels to nitrocellulose sheets: procedure and some applications. Proceedings of the National Academy of Sciences of the United States of America 76, $4350-4354$. 
WATT, B. (1972). The recovery of clinically important anaerobes on solid media. Journal of Medical Microbiology 5, 211218.

WEEKE, B. (1973). Crossed immunoelectrophoresis. Scandinatian Journal of Immunology 2, Suppl. 1, 47 56 .
Wideman, P. A., Vargo, V. L., Citronbaum, D. \& FINEGOLD, S. M. (1976). Evaluation of the sodium polyanethol sulfonate disk test for identification of Peptostreptococcus anaerobius. Journal of Clinical Microbiology 4, 330-333. 